\title{
Cytotoxic activity of Shp2 inhibitor fumosorinone in human cancer cells
}

\author{
CHUAN CHEN $^{1}$, TONGDAN XUE ${ }^{1}$, PENG FAN $^{1}$, LINLIN MENG $^{1}$, JINGJING WEI $^{2}$ and DUQIANG LUO ${ }^{1,2}$ \\ ${ }^{1}$ College of Life Science, Key Laboratory of Medicinal Chemistry and Molecular Diagnosis of The Ministry of Education; \\ ${ }^{2}$ College of Pharmaceutical Science, Hebei University, Baoding, Hebei 071002, P.R. China
}

Received September 20, 2017; Accepted January 29, 2018

DOI: $10.3892 / 01.2018 .8593$

\begin{abstract}
Fumosorinone (Fumos) isolated from entomogenous fungi Isaria fumosorosea exhibited selective inhibition of Src homology phosphotyrosine phosphatase 2 inhibitor (Shp2) in our previous study. The purpose of the present study was to investigate the effects of Fumos on cell cycle arrest, tumor cell migration and the in vitro antiproliferative activity of Fumos alone or in combination with the commonly used cytotoxic drugs 5-fluoracil (5-FU) and p38 inhibitor SB203580. Fumos exhibited cytotoxicity against selected human cancel lines, including HeLa, MDA-MB-231 and MDA-MB-453 cell lines. Fumos exerted selective cytotoxic effects on the human cell lines. Flow cytometric and DAPI assays showed that Fumos did not induce cell apoptosis, however it induced cell cycle arrest at the G1 phase. Fumos inhibited cell migration though reducing the phosphorylation of focal adhesion kinase (FAK) at tyrosine (Tyr)861 and marginally increasing the phosphorylation of FAK at Tyr397, however, Fumos did not affect the phosphorylation of FAK at Tyr576 or Tyr925. The present study also examined the combination effect of Fumos with other chemical agents, including 5-FU and p38 inhibitor SB203580. Fumos exhibited a marked synergistic effect with these agents, particularly with 5-FU. In conclusion, Fumos showed potential anticancer bioactivity, and the combination effect of Fumos with 5-FU or with p38 inhibitor offers a more effective anticancer strategy for carcinoma treatment.
\end{abstract}

\section{Introduction}

Src homology phosphotyrosine phosphatase 2 (Shp2) encoded by PTPN11 is a non-receptor protein tyrosine phosphatase (PTP), which is important in cell signal transudation. Shp2

Correspondence to: Professor Dugiang Luo, College of Life Science, Key Laboratory of Medicinal Chemistry and Molecular Diagnosis of The Ministry of Education, Hebei University, $180 \mathrm{Wu}$ Si East Street, Baoding, Hebei 071002, P.R. China

E-mail: duqiangluo@163.com

Key words: fumosorinone, Src homology phosphotyrosine phosphatase 2 inhibitor, cytotoxicity, synergism was the first confirmed proto-oncogene among the PTP superfamily (1). It composes two tandem SH2 domains at the $\mathrm{N}$-terminus and a PTP domain at the C-terminus (2). Shp2 can form an intramolecular interface between the $\mathrm{N}-\mathrm{SH} 2$ domain and the PTP domain. Upon activation, N-SH2 domains can bind phosphotyrosine residues and activate the activity of Shp2 by interrupting the self-inhibitory interaction between $\mathrm{N}-\mathrm{SH} 2$ and PTP domains (3). Shp2 has an overall positive effect in transducing signals for a wide array of cytokines and growth factors. It acts downstream of several receptors, including Met receptor, fibroblast growth factor receptor, epidermal growth factor receptor and insulin receptor, and is involved in multiple cell signaling processes, including the Ras-extracellular signal-regulated kinase (ERK), phosphoinositide 3-kinase-Akt, Janus kinase-signal transducer and activator of transcription, nuclear factor- $\kappa \mathrm{B}$, and mammalian target of rapamycin pathways (4).

Germline or somatic mutations in PTPN11 are associated with Noonan syndrome, LEOPARD syndrome and juvenile myelomonocytic leukemia (5). The overexpression of Shp2 is also involved in human cancer $(6,7)$, however, the signaling mechanisms of Shp2 in cancer remain to be fully elucidated. There are several conflicting reports on the association between Shp2 and cancer. Certain studies have found that the expression of Shp2 decreases in certain types of tumor (8-10). However, the opposite was concluded in hepatocellular carcinoma (11-13). Shp2 is predominantly localized in the cytoplasm matrix, however, localization in other cellular subcompartments, including the nucleus and the mitochondria, has also been found $(14,15)$. The different cellar localization suggests the different functions of Shp2. Determining the function of Shp2 in these organelles is likely to assist in understanding the molecular mechanisms involved in Shp2-associated tumorigenesis.

Several Shp2 inhibitors have been identified (16-21). It is noteworthy that the Shp2 inhibitor, SHP099, which maintains Shp2 in an auto-inhibited conformation, shows potent antitumor efficacy in mouse tumor xenograft models (22).

In our previous study, the novel compound, fumosorinone (Fumos) was identified using a PTP enzyme-screening assay (Fig. 1A). It showed high selectivity towards Shp2, compared with other PTPs. Fumos inhibited Shp2-mediated cell signaling without notable off-target effects in human cancer lines (23). In the present study, the cytotoxic activity of Fumos 
on different human cell lines, and its effect on cell cycle arrest and tumor cell migration were examined. The investigation focused on the tyrosine (Tyr) phosphorylation of FAK involved in cell migration regulated by Shp2. The combination effect of Fumos with other inhibitors, including 5-fluoracil (5-FU) and p38 inhibitor, was also detected.

\section{Materials and methods}

Chemicals and antibodies. Fumos was isolated and purified with a purity of $99 \%$ according to the methods described by Chen et al (23). Phosphorylated (p-) FAK pTyr861 (cat. no. 11059), p-FAK pTyr576 (cat.no. 11545) and p-FAK pTyr925 (cat. no. 11123) antibodies were purchased from Signal way Antibody LLC (College Park, MD, USA), FAK (cat. no. 3285) and p-FAK pTyr397 (cat. no. 3283) antibodies were purchased from Cell Signaling Technology, Inc. (Danvers, MA, USA). GADPH (cat. no. sc-47724) antibody was purchased from Santa Cruz Biotechnology, Inc. (Dallas, TX, USA). Goat anti-rabbit IgG (H+L), HRP conjugate (cat. no. SA00001-2) and Goat anti-mouse $\operatorname{IgG}(\mathrm{H}+\mathrm{L})$, HRP conjugate (cat. no. SA00001-1) antibodies were purchased from ProteinTech Group, Inc. (Chicago, IL, USA). 5-FU and SB203580 were purchased from Sigma-Aldrich (Merck KGaA, Darmstadt, Germany). Polyvinylidene fluoride (PVDF) was obtained from EMD Millipore (Billerica, MA, USA).

Cell culture. All cell lines were purchased from the Type Culture Collection of the Chinese Academy of Sciences (Shanghai, China). The HeLa cells were cultured in Dulbecco's modified Eagle's medium (HyClone; GE Healthcare Life Sciences, Logan, UT, USA), and the MDA-MB-231 and MDA-MB-453 cells were cultured in RPMI 1640 medium supplemented with $10 \%$ fetal bovine serum (HyClone; GE Healthcare Life Sciences) at $37^{\circ} \mathrm{C}$, under $95 \%$ air and $5 \% \mathrm{CO}_{2}$.

MTT assay. The exponentially growing cells $\left(5 \times 10^{3}\right)$ were cultured in 96-well plates with $100 \mu \mathrm{l}$ medium and treated with $0,2.5,5,10,20$ and $40 \mu \mathrm{g} / \mathrm{ml}$ Fumos dissolved in DMSO at $37^{\circ} \mathrm{C}$, under $5 \% \mathrm{CO}_{2}$ and $95 \%$ air for 24,48 and $72 \mathrm{~h}$, The DMSO concentration was maintained $<0.5 \%$. Subsequently, $20 \mu \mathrm{l}(5 \mathrm{mg} / \mathrm{ml})$ of MTT was added to each well, and the plates were incubated at $37^{\circ} \mathrm{C}$ for $4 \mathrm{~h}$, following which $100 \mu \mathrm{l}$ of $0.01 \mathrm{M} \mathrm{SDS}-\mathrm{HCl}$ was added prior to incubation at $37^{\circ} \mathrm{C}$ overnight. The absorbance at $570 \mathrm{~nm}$ was detected using a microplate reader (Thermo Fisher Scientific, Inc., Waltham, MA, USA).

Wound-healing motility assay. The cells reached 70-80\% confluence as a monolayer in 6-well plates. A scratch across the center of the monolayer was created in each well using a 200- $\mu$ l pipette tip, and the cells were then serum-starved for $12 \mathrm{~h}$, following which $20 \mathrm{ng} / \mathrm{ml}$ epidermal growth factor (EGF) and 0.5 and $2 \mu \mathrm{g} / \mathrm{ml}$ Fumos were added. Images of each well were captured under an IX53 inverted fluorescence microscope (Olympus Corporation, Tokyo, Japan).

Western blot analysis. The cells were incubated and dissolved in lysis buffer (50 mM Hepes- $\mathrm{NaOH}, 100 \mathrm{mM} \mathrm{NaCl}, 2.5 \mathrm{mM}$ EDTA, 0.5\% NP-40, 10\% glycerol, 1 mM PMSF, 1 mM DTT,
$2 \mu \mathrm{g} / \mathrm{ml}$ aprotinin, $0.7 \mu \mathrm{g} / \mathrm{ml}$ pepstatin, $0.5 \mu \mathrm{g} / \mathrm{ml}$ leupetin and $2 \mu \mathrm{g} / \mathrm{ml}$ aprotinin). The cell lysates were centrifuged at $12,000 \mathrm{~g}$ for $10 \mathrm{~min}$ at $4^{\circ} \mathrm{C}$, following which the supernatant was collected and the protein concentration was determined using the Bradford assay. The proteins $(30 \mu \mathrm{g})$ were denatured in sample buffer and loaded onto a $10 \%$ sodium dodecyl sulfate-polyacrylamide gel. Following electrophoresis, the proteins were transferred onto a PVDF membrane. The PVDF membrane was blocked with 5\% non-fat milk powder (w/v) for $1 \mathrm{~h}$ at room temperature, and then incubated with specific primary/HRP-conjugated secondary antibodies. All the primary antibodies were diluted at 1:1,000 and the secondary antibodies were diluted at 1:2,000. PVDF membranes were incubated in the antibody solution for $1 \mathrm{~h}$ at room temperature. The anti-GAPDH antibody was used to ensure equal protein loading. The bands were visualized with ECL reagent and exposed with FUJI X-ray films (FUJIFILM Corporation, Tokyo, Japan). Photoshop CS6 (Adobe Systems Inc; San Jose, CA, USA) was used for grayscale analysis after scanning the band of exposed X-ray films.

Cell analysis by flow cytometry. The cells were treated with Fumos at a concentration of $0,5,10,15$ or $20 \mu \mathrm{g} / \mathrm{ml}$ in a six-well plate at a density of $2 \times 10^{5}$ cells/well for $24 \mathrm{~h}$ and then collected by centrifugation at $600 \mathrm{x}$ g for $5 \mathrm{~min}$, following which they were washed twice with ice-cold PBS. The cells were treated according to the Cycle test Plus DNA Reagent kit protocol (BD Biosciences, Franklin Lakes, NJ, USA). A total of 10,000 cells were analyzed. Cell cycle distribution was analyzed with flow cytometry (FACSCalibur; BD Biosciences, NJ, USA). An apoptotic assay was performed using the Annexin V-FITC Apoptosis Detection kit (BD Biosciences).

Immunofluorescence technique. The HeLa cells were seeded onto a polylysine-coated glass coverslip in a 24 -well plate at a density of $2 \times 10^{3}$ cells/well. The cells were treated with $20 \mu \mathrm{g} / \mathrm{ml}$ Fumos for $48 \mathrm{~h}$, with DMSO used as a control. The cells were washed with PBS three times and stained with $1 \mathrm{ng} / \mathrm{ml}$ DAPI. Images of the cells were captured using an Olympus IX53 fluorescence microscope.

Drug combination evaluation. The cells were treated with 5-FU (30, 60 and $120 \mu \mathrm{g} / \mathrm{ml})$ or SB203580 (12.5, 25 and $50 \mu \mathrm{g} / \mathrm{ml})$ alone or in combination with Fumos $(5,10$ and $15 \mu \mathrm{g} / \mathrm{ml}$ ). Cell viability was assessed using the MTT assay. Synergism, additivity and antagonism were quantified by determining the combination index (CI), which was calculated by the Chou-Talalay equation using CalcuSyn software version 2.1 (Biosoft, Cambridge, UK).

Statistical analysis. SPSS software version 12 (SPSS, Inc., Chicago, IL, USA) was used for statistical analysis. Statistical significance of differences was assessed using one-way analysis of variance followed by a Tukey's post hoc test for multiple comparisons. $\mathrm{P}<0.01$ was considered to indicate a statistically significant difference.

\section{Results}

Effect of Fumos on cell viability in different cell lines. It was identified that Fumos inhibited the proliferation of the HeLa, 

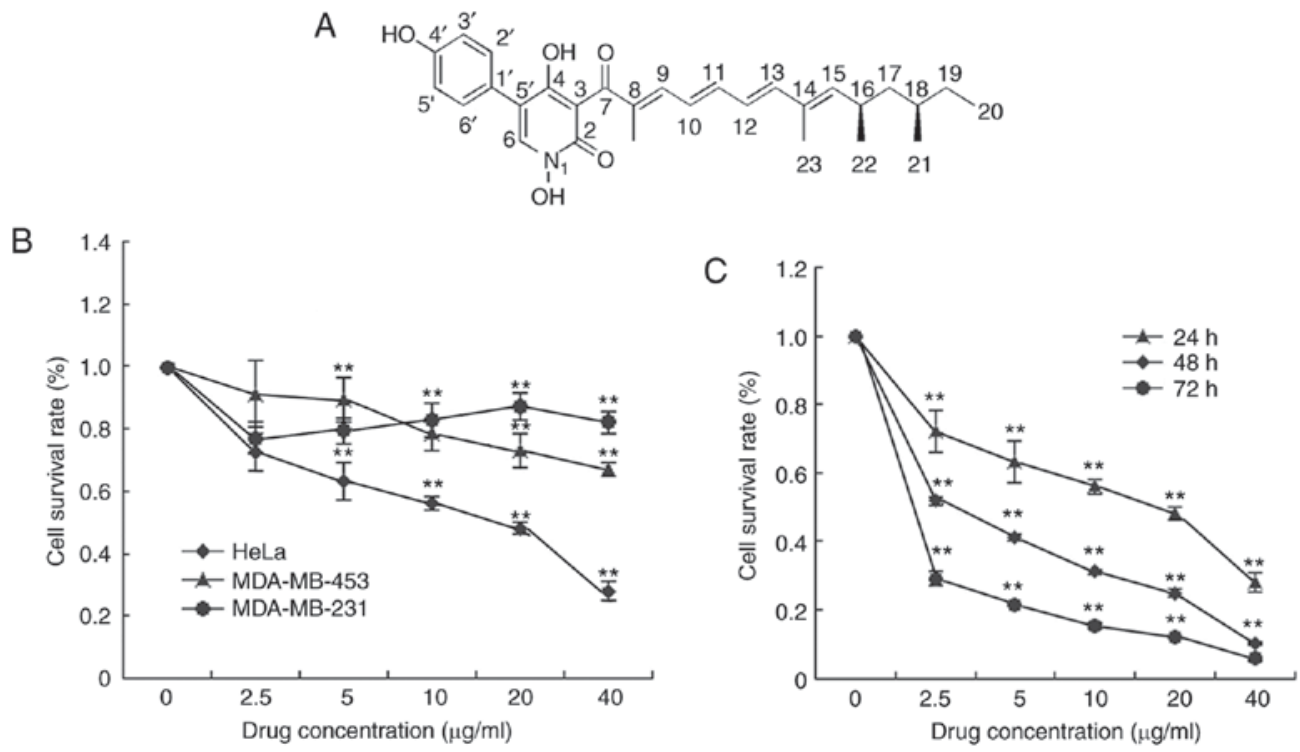

Figure 1. Effect of Fumos on the viability of different cell lines. (A) Structure of Fumos. (B) Cell proliferation was examined using the MTT assay. Cells were treated with 2.5, 5,10, 20 and $40 \mu \mathrm{g} / \mathrm{ml}$ Fumos, or with DMSO (0.5\%) as the vehicle control, for $24 \mathrm{~h}$. The data are expressed as the mean \pm standard deviation of three independent experiments. (C) HeLa cells were treated with 2.5, 5,10, 20 and $40 \mu \mathrm{g} / \mathrm{ml}$ Fumos, or with DMSO (0.5\%) as the vehicle control, for 24, 48 and $72 \mathrm{~h} .{ }^{* *} \mathrm{P}<0.01$, vs. untreated cells. One-way analysis followed by Tukey's test was performed. Fumos, fumosorinone.

MDA-MB-231 and MDA-MB-453 human cells to different degrees. Treatment with Fumos for 24 h showed cytotoxicity against $\mathrm{HeLa}\left(\mathrm{IC}_{50} 11 \mu \mathrm{g} / \mathrm{ml}\right)$ and MDA-MB-231 $\left(\mathrm{IC}_{50} 30 \mu \mathrm{g} / \mathrm{ml}\right)$ and MDA-MB-453 ( $\mathrm{IC}_{50} 31 \mu \mathrm{g} / \mathrm{ml}$ ) cells (Fig. 1B). Fumos showed the highest cytotoxicity towards HeLa cells. Fumos also exhibited potent cytotoxicity against the HeLa cell line over $48 \mathrm{~h}\left(\mathrm{IC}_{50} 5 \mu \mathrm{g} / \mathrm{ml}\right)$ and $72 \mathrm{~h}\left(\mathrm{IC}_{50} 3 \mu \mathrm{g} / \mathrm{ml} ;\right.$ Fig. 1C). This showed that Fumos inhibited the proliferation of HeLa cells in a time- and dose-dependent manner. All data indicated that Fumos exhibited selective cytotoxic effects towards different human cell lines.

Effect of Fumos on cell apoptosis and cell cycle. As Fumos inhibited the proliferation of human cells, the present study also examined whether Fumos induced cell apoptosis. Based on the $\mathrm{IC}_{50}$ values, four concentrations of Fumos $(0,5,10$, 15 and $20 \mu \mathrm{g} / \mathrm{ml}$ ) were selected to detect the cell change at $48 \mathrm{~h}$. Cell death and detachment from the culture dishes leads to no cells being detected under higher concentrations of Fumos, whereas very low concentrations of Fumos may induce no changes in the cells (data not shown). A DAPI assay was used to detect the nuclear changes and apoptotic body formation, which are characteristic of apoptosis. The nuclear shape was intact following Fumos treatment in the HeLa cells (Fig. 2A). In the MDA-MB-231 cells, the nuclear shape was also unchanged (data not shown). The cytometric apoptosis assays also showed that Fumos did not induce cell apoptosis in the HeLa or MDA-MB-231 cells. The results of the highest concentration treatment $(20 \mu \mathrm{g} / \mathrm{ml})$ at $48 \mathrm{~h}$ are shown in Fig. 2B. Subsequently, the present study examined whether Fumos induced cell cycle arrest. As shown in Fig. 3, Fumos induced cell cycle arrest at the G1 phase. Following treatment for $24 \mathrm{~h}$, Fumos increased the percentage of HeLa cells in the G1 phase from 69.01 to $79.72 \%$, compared with control. Fumos also caused the accumulation of MDA-MB-231 cells in the G1 phase from 53.81 to $69.82 \%$.
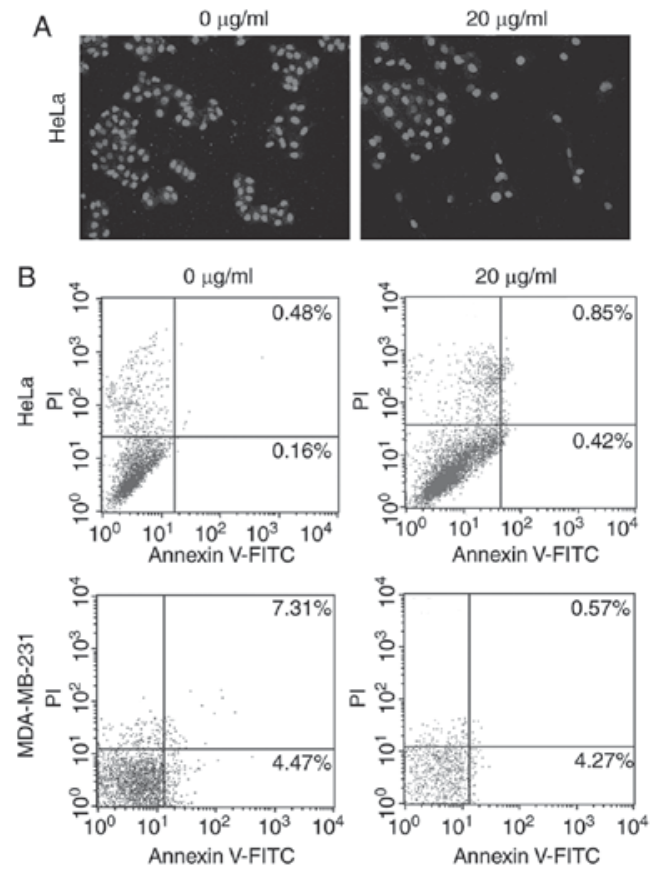

Figure 2. Fumos does not induce apoptosis of HeLa cells or MDA-MB-231 cells. (A) HeLa cells were treated with $20 \mu \mathrm{g} / \mathrm{ml}$ Fumos for $48 \mathrm{~h}$, or with $0.5 \%$ DMSO as a control. Cells were washed with PBS three times, stained with $1 \mathrm{ng} / \mathrm{ml}$ DAP1 for $5 \mathrm{~min}$ and then washed again with PBS three times. Cell morphology was observed using fluorescence microscopy (magnification, x400). (B) HeLa cells and MDA-MB-231 cells were treated with $20 \mu \mathrm{g} / \mathrm{ml}$ Fumos for $48 \mathrm{~h}$, and apoptosis was analyzed using flow cytometry. Annexin V and PI staining was performed. Each value represents the average of three independent experiments. Fumos, fumosorinone; PI, propidium iodide.

Effect of Fumos on tumor cell migration. Increasing data have shown that Shp2 is linked to cell migration (6). To examine the effect of Fumos on cell migration, a wound healing assay was used in the presence of 0.5 and $2 \mu \mathrm{g} / \mathrm{ml}$ Fumos. As shown in Fig. 4,EGF notably induced cell migration and increased the rate 

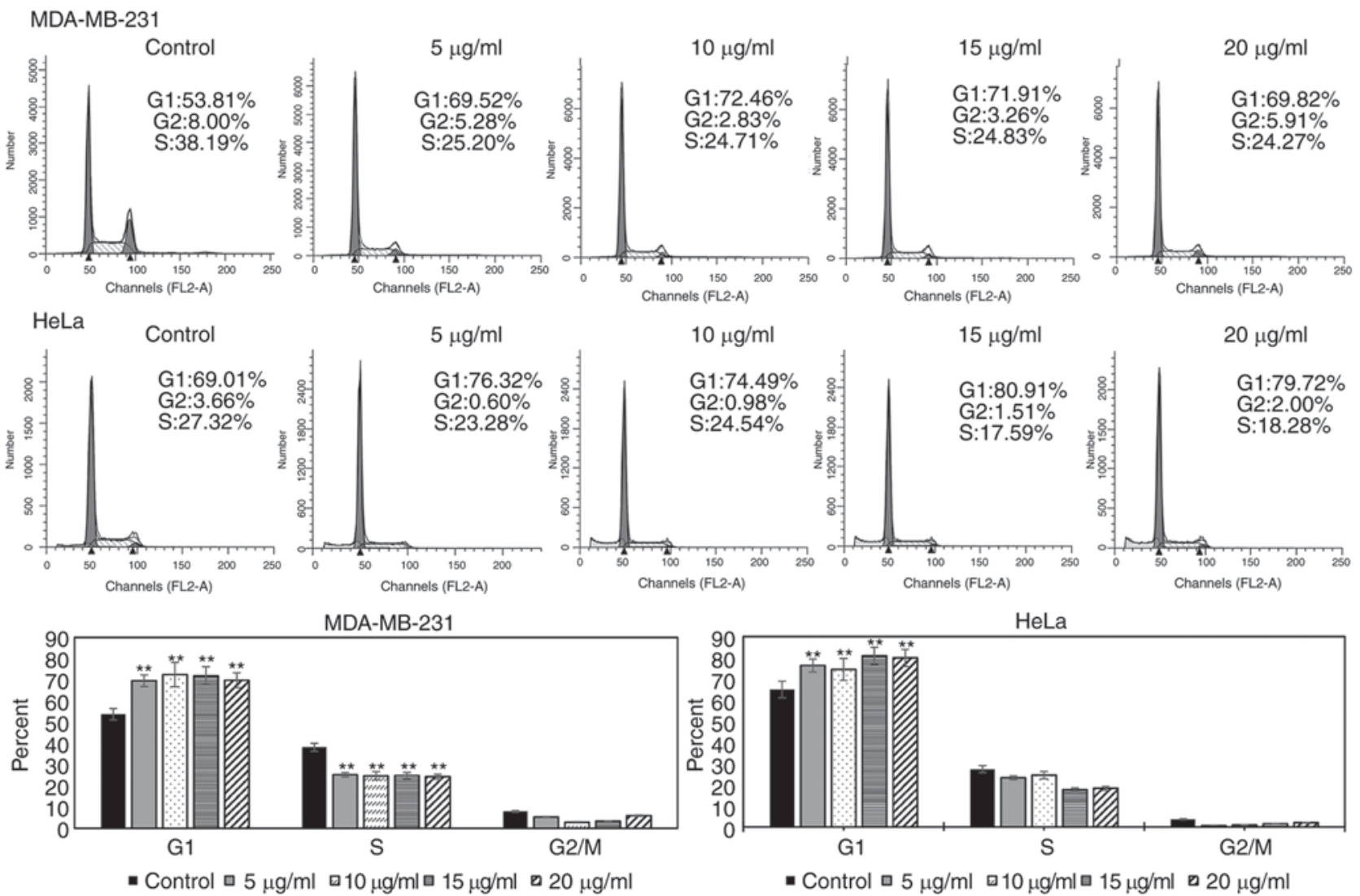

Figure 3. Effect of Fumos on cell cycle in HeLa cells and MDA-MB-231 cells. Cells were treated with Fumos $(0,5,10,15$ and $20 \mu \mathrm{g} / \mathrm{ml})$ for $24 \mathrm{~h}$ and analyzed for propidium iodide-stained DNA content using flow cytometry. Each experiment was performed in triplicate. The histograms show results of statistical analysis. ${ }^{* *} \mathrm{P}<0.01$, vs. control. One-way analysis of variance followed by Tukey's test was performed. Fumos, fumosorinone.
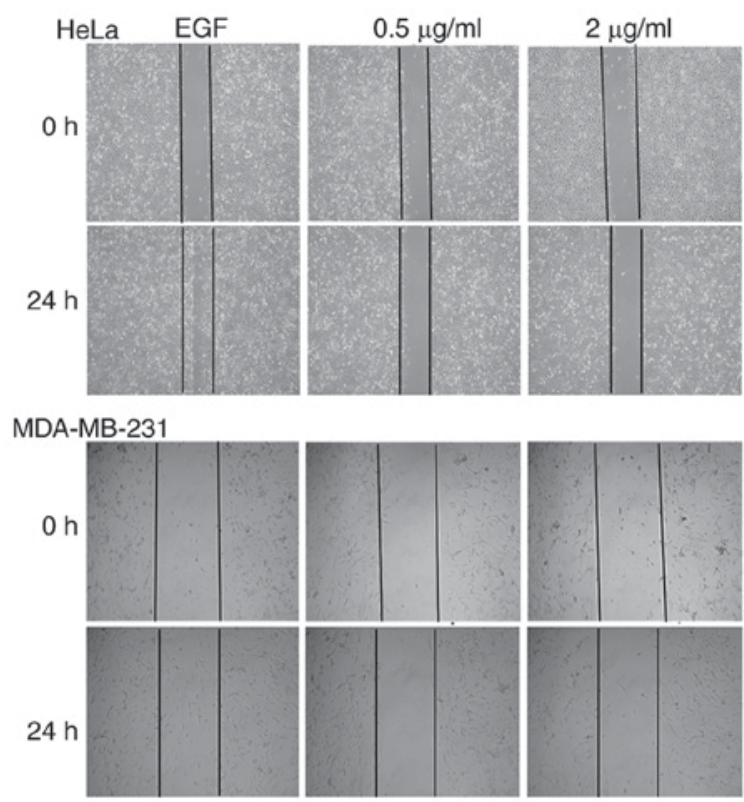

Figure 4. Fumos inhibits EGF-induced cell migration. The 90\% confluent monolayers of cells were wounded via a scratch, following which they were serum-starved for $12 \mathrm{~h}$, and then incubated with 0.5 and $2 \mu \mathrm{g} / \mathrm{ml}$ Fumos and EGF (20 ng/ml) for $24 \mathrm{~h}$. Cells were observed using microscopy (x100 magnification). Fumos, fumosorinone; EGF, epidermal growth factor.

of closure of the gap in the HeLa cells and MDA-MB-231 cells. Fumos decreased the closure of the gap in the two cell lines. In addition, the maximum concentration of $7 \mu \mathrm{g} / \mathrm{ml}$ Fumos was used to examine its effect on cell migration. The higher concentration also inhibited cell migration (data not shown). There was no notable cell growth inhibition under these concentrations of Fumos, thus the inhibition of cell migration was not due to the cytotoxicity of Fumos. These results indicated that Fumos caused the significant inhibition of tumor migration.

Effect of Fumos on the phosphorylation of FAK involved in tumor cell migration. Hartman et al (24) found that Shp2 promoted EGF-induced cell movement by regulating the activity of FAK through dephosphorylating p-Tyr397. As Fumos inhibited the migration of the HeLa and MDA-MB-231 cells, the present study examined whether Fumos affected the phosphorylation of FAK involved in cell migration. Fumos marginally increased the level of pTyr397, but had no effect on the phosphorylation of pTyr576 or pTyr925 in the two cell lines (Fig. 5). Fumos inhibited the phosphorylation at pTyr861 of FAK in the HeLa cells, whereas the inhibited phosphorylation of pTyr861 was only observed at a high concentration of Fumos in the MDA-MB-231 cells. This indicated that Shp2 regulated the phosphorylation of FAK in a different manner depending on the cell type.

Combination effect of Fumos with other agents. 5-fluoracil (5-FU) is a potent, small-molecule DNA synthesis inhibitor, and is widely used in chemotherapy for cancer treatment. 5-FU can induce DNA damage and replication stress, and disrupt the 


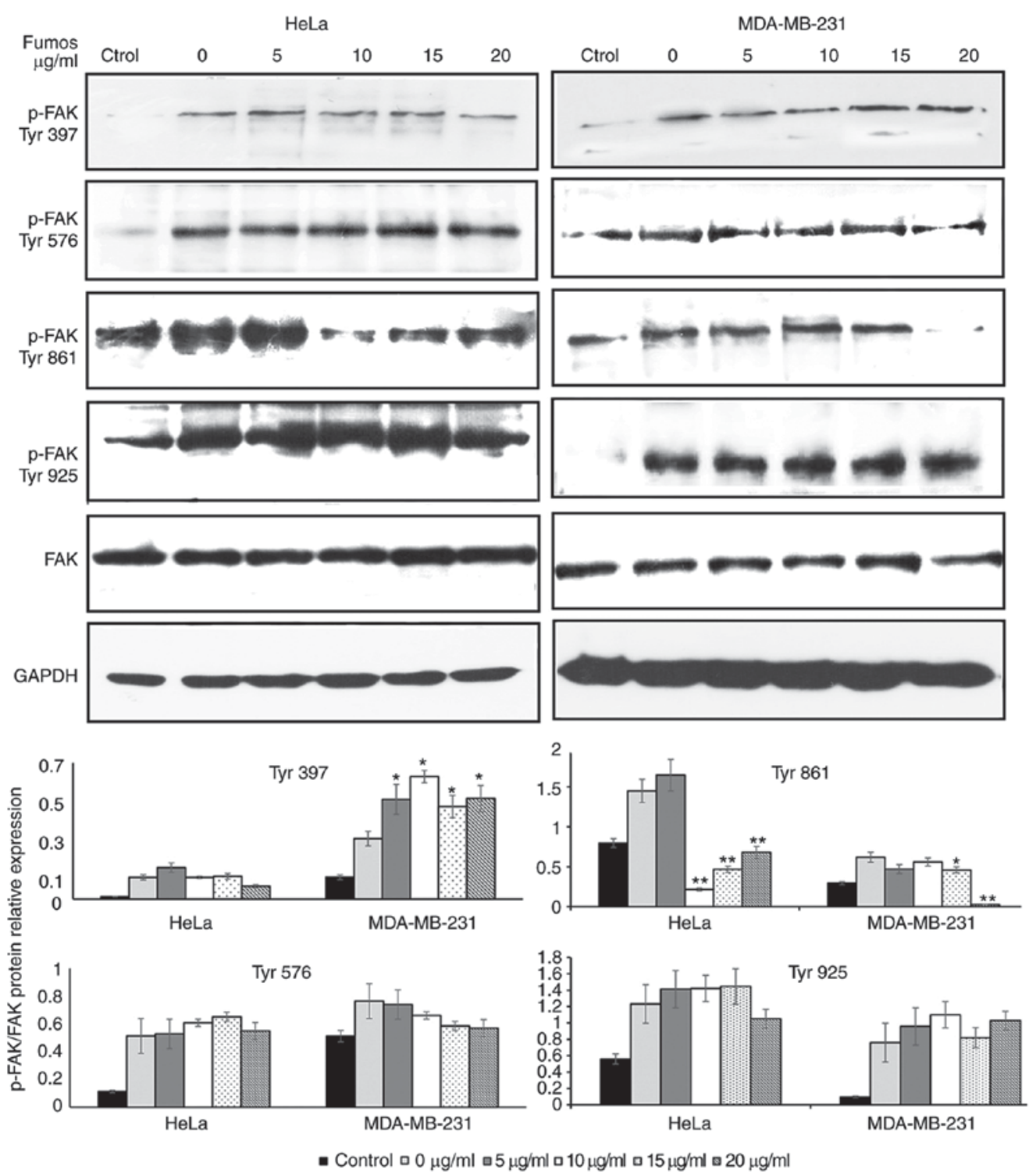

Figure 5. Effect of Fumos on the phosphorylation of FAK. Serum starved cells were pretreated with various concentrations of Fumos $(0,5,10,15 \mathrm{and} 20 \mu \mathrm{g} / \mathrm{ml})$ for $24 \mathrm{~h}$ and then stimulated with EGF ( $20 \mathrm{ng} / \mathrm{ml}, 5 \mathrm{~min}$ ). Western blot analysis of the phosphorylation of FAK at sites $397,576,861$ and 925 was performed. The histograms show the results of statistical analysis. " $\mathrm{P}<0.05$ and ${ }^{* *} \mathrm{P}<0.01$, vs. control. One-way analysis of variance followed by Tukey's test was performed. Fumos, fumosorinone; FAK, focal adhesion kinase; EGF, epidermal growth factor; p-, phosphorylated.

genome stability, whereas Shp2 can maintain genome stability. The present study investigated whether the Shp2 inhibitor, Fumos, increased the sensitivity to 5-FU. The combination effect of 5-FU and Fumos led to more potent inhibition of HeLa cells, compared with the single treatment (Fig. 6A). Using CalcuSyn software, the combined anti proliferative effects were examined. The resulting CI theorem of Chou-Talalay offers quantitative definition for additive effect $(\mathrm{CI}=1)$, synergism $(\mathrm{CI}<1)$, and antagonism $(\mathrm{CI}>1)$ in drug combinations. A synergistic effect with low CIs $(\mathrm{CI}<1)$ was found (Fig. 6B). The data showed that Fumos synergized with 5-FU in suppressing cell growth. SB203580 is a p38 mitogen-activated protein kinase (MAPK) inhibitor. The combination of Fumos and p38 MAPK inhibitor increased the cell death (Fig. 6C). At a low concentration of SB203580, combination with Fumos showed no synergism $(\mathrm{CI}>1)$. However, at a higher concentration of SB203580, synergism was detected $(\mathrm{CI}<1$; Fig. 6D). These results indicated that the combination of Shp2 inhibitor with p38 MAPK inhibitor or 5-FU resulted in the synergistic enhancement of growth inhibition.

\section{Discussion}

In our previous study, a novel Shp2 inhibitor, Fumos was identified. It inhibited the Shp2-dependent activation of the Ras/ERK signaling pathway induced by EGF (23). In the present study, the cytotoxity of Fumos towards different cancer cell lines was examined. Fumos showed varying degrees of cytotoxicity towards the human cell lines, and this result suggested that Shp2-mediated cell signals have various roles in different cell lines. The mechanism underlying the cytotoxic effects of Fumos towards cells was also examined. Flow cytometric assays showed that Fumos induced cell arrest at the G1 phase, but did not cause cell apoptosis.

Shp2 is also important in cell migration $(25,26)$. Shp2 has been shown to mediate tyrosine dephosphorylation of FAK. 
A

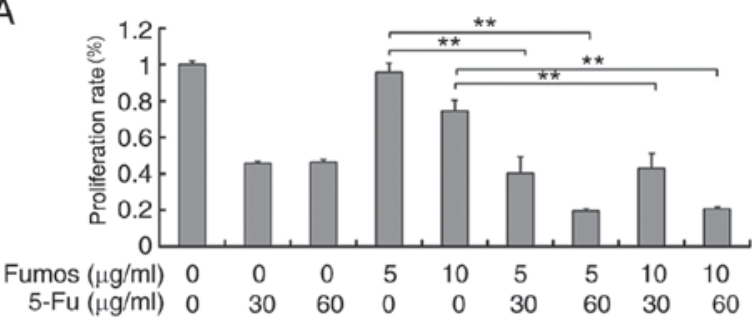

B
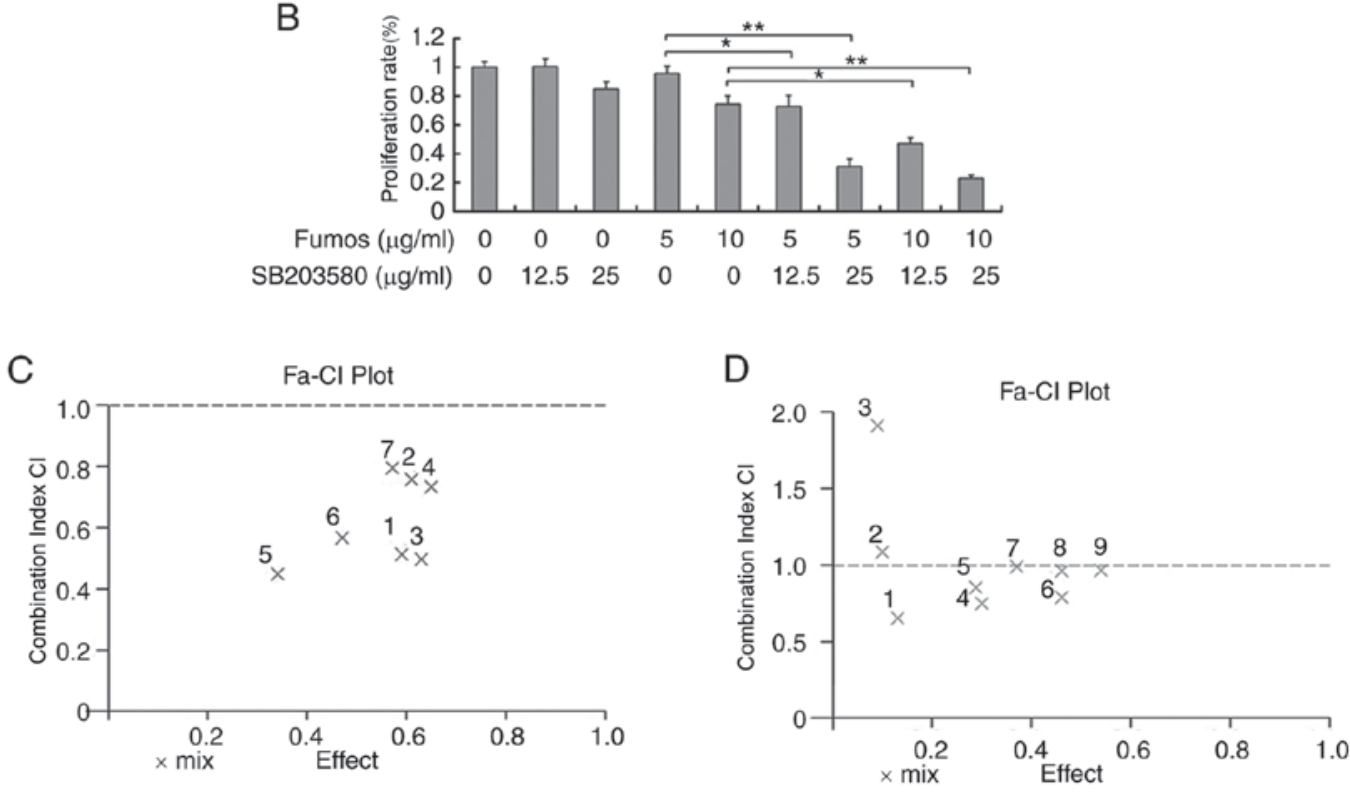

Figure 6. Combination effect of Fumos with other agents. Cells were treated with various concentration of (A) 5-FU and a (B) CI/fractional effect curve was calculated using CalcuSyn software in HeLa cells. Cells were treated with various concentrations of (C) SB203580 alone or in combination with Fumos and a (D) $\mathrm{CI} /$ fractional effect curve was calculated using CalcuSyn software in HeLa cells. Values are presented as the mean \pm standard error of the mean of three experiments. ${ }^{* *} \mathrm{P}<0.01$ and ${ }^{*} \mathrm{P}<0.05$. One-way analysis of variance followed by Tukey's test was performed. CI values $>1$ represents an antagonistic effect, $\mathrm{CI}=1$ represents an additive effect, $\mathrm{CI}<1$ represents a synergistic effect. The combination effect was assessed with each concentration of 5-FU (30, 60 and $120 \mu \mathrm{g} / \mathrm{ml})$ and SB203580 $(12.5,25$ and $50 \mu \mathrm{g} / \mathrm{ml})$ and the corresponding three concentrations of Fumos (5, $10 \mathrm{and} 15 \mu \mathrm{g} / \mathrm{ml})$. CI, combination index; 5-FU, 5-fluoracil.

FAK is a cytoplasmic tyrosine kinase, which is important in cell migration (27). However, the major phosphorylation sites of FAK regulated by Shp2 remain to be fully elucidated. The phosphorylation of FAK was found to be moderately upregulated upon Shp2 knockdown in prostate cancer cells and MCF7 cells $(28,29)$. In Shp2-mutant Schwann cells, the phosphorylation of FAK on Tyr925 and Tyr576/577, but not on Tyr397, was markedly downregulated, however, in neural stem cells, Shp2 only affected the phosphorylation of FAK on Tyr397 $(30,31)$. The tyrosine phosphorylation of FAK and p130Cas has also been reported to be unaffected by the inhibition of Shp2 in certain cells (32). Fumos marginally increased pTyr397, had no effect on phosphorylation at pTyr576 or pTyr925, and reduced pTyr861 in the two cell lines. This discrepancy may be due to differences in Shp2 regulating the signaling systems in the different types of cells. Shp2 may mediate the activation as well as inactivation of FAK. It is important to investigate whether Shp2 at other sites regulates the phosphorylation of FAK. The association between FAK and Shp2 requires further investigation.

Until now, only several highly selective Shp2 inhibitors have been reported. There are no reports of the combination effect of Shp2 inhibitor and other chemical agents. The present study examined the combined anticancer effect of Fumos with 5-FU or p38 MAPK inhibitor.

5-FU is a DNA synthesis inhibitor, which inhibits the synthesis of DNA by inhibiting thymidine synthetase. 5-FU is commonly used in combination chemotherapeutic programs for cancer patients. Drug toxicity and resistance remain a significant limitation in the clinical use of 5-FU (33). Novel therapeutic strategies are urgently required to improve 5-FU sensitivity and cellular responses. The Shp2 inhibitor, Fumos, synergizes with 5-FU in suppressing cell growth. This is a novel strategy to improve 5-FU sensibility. 5-FU can activate certain kinases involved in cell cycle checkpoints and DNA repair, which are important for drug resistance (34). Shp2 is also important for DNA replication and damage checkpoints (35). Whether DNA damage checkpoints are involved in the synergistic effect between Fumos and 5-FU requires further investigation.

p38 MAPK is important in a wide variety of cellular functions in response to a range of stimuli involved in cell survival, cell death, cell inflammation and immune modulation (36). p38 MAPK is also an attractive target for intervention in certain types of solid tumor (37). The overexpression of Shp2 can increase p38 enzyme activity (38). The Shp2 inhibitor, Fumos, synergized with $\mathrm{p} 38$ inhibitor in suppressing cell growth. These 
findings demonstrated novel drug combinations, which may potentiate the effectiveness of Shp2 inhibitor-based treatments.

In conclusion, Fumos was shown to exhibit potent anticancer properties alone and in combination with 5-FU and p38 MAPK inhibitor. Therefore, the combination treatment of Fumos and 5-FU or p38 MAPK inhibitor may serve as a novel effective anticancer strategy for cancer treatment.

\section{Acknowledgements}

Not applicable.

\section{Funding}

This study was financially supported by the National Natural Science Foundation of China (grant no. 31371957), the Changjiang Scholars and Innovative Research Team in University (grant no. IRT_15R16), the Foundation for High-level Talents in Higher Education of Hebei, China (grant no. GCC2014034) and The National Key Research and Development Program of China (grant nos. 2017YFD0201400 and 2017YFD0201401).

\section{Availability of data and materials}

The datasets used and/or analyzed during the present study are available from the corresponding author on reasonable request.

\section{Authors' contributions}

CC and TDX performed the experiment. CC, TDX, PF, JJW and LLM analyzed and interpreted the data. CC and DQL were major contributors in writing and revising it critically for important intellectual content. CC and DQL made substantial contributions to conception and design. All authors read and approved the final manuscript.

\section{Ethics approval and consent to participate}

Not applicable.

\section{Consent for publication}

Not applicable.

\section{Competing interests}

The authors declare that they have no competing interests.

\section{References}

1. Mohi MG and Neel BG: The role of Shp2 (PTPN11) in cancer. Curr Opin Genet Dev 17: 23-30, 2007.

2. He RJ, Yu ZH, Zhang RY and Zhang ZY: Protein tyrosine phosphatases as potential therapeutic targets. Acta Pharmacol Sin 35 1227-1246, 2014.

3. Chan G, Kalaitzidis D and Neel BG: The tyrosine phosphatase Shp2 (PTPN11) in cancer. Cancer Metastasis Rev 27: 179-192, 2008.

4. Matozaki T, Murata Y, Saito Y, Okazawa H and Ohnishi H: Protein tyrosine phosphatase SHP-2: A proto-oncogene product that promotes Ras activation. Cancer Sci 100: 1786-1793, 2009.
5. Yang W, Wang J, Moore DC, Liang H, Dooner M, Wu Q, Terek R, Chen Q, Ehrlich MG, Quesenberry PJ and Neel BG: Ptpn11 deletion in a novel progenitor causes metachondromatosis by inducing hedgehog signalling. Nature 499: 491-495, 2013.

6. Aceto N, Sausgruber N, Brinkhaus H, Gaidatzis D, Martiny-Baron G, Mazzarol G, Confalonieri S, Quarto M, Hu G, Balwierz PJ, et al: Tyrosine phosphatase SHP2 promotes breast cancer progression and maintains tumor-initiating cells via activation of key transcription factors and a positive feedback signaling loop. Nat Med 18: 529-537, 2012.

7. Zhan Y, Counelis G and O'Rourke D: The protein tyrosine phosphatase SHP-2 is required for EGFRvIII oncogenic transformation in human glioblastoma cells. Exp Cell Res 315: 2343-2357, 2009

8. Jiang C, Hu F, Tai Y, Du J, Mao B, Yuan Z, Wang Y and Wei L: The tumor suppressor role of Src homology phosphotyrosine phosphatase 2 in hepatocellular carcinoma. J Cancer Res Clin Oncol 138: 637-646, 2012.

9. Tassidis H, Brokken LJ, Jirström K, Bjartell A, Ulmert D, Härkönen P and Wingren AG: Low expression of SHP-2 is associated with less favorable prostate cancer outcomes. Tumor Biol 34: 637-642, 2013.

10. Yu SJ, Yu JK, Ge WT, Hu HG, Yuan Y and Zheng S: SPARCL1, Shp2, MSH2, E-cadherin, p53, ADCY-2 and MAPK are prognosis-related in colorectal cancer. World J Gastroenterol 17: 2028-2036, 2011

11. Han T, Xiang D-M, Sun W, Liu N, Sun HL, Wen W, Shen WF, Wang RY, Chen C, Wang X, et al: PTPN11/Shp2 overexpression enhances liver cancer progression and predicts poor prognosis of patients. J Hepatol 63: 651-660, 2015.

12. Bard-Chapeau EA, Li S, Ding J, Zhang SS, Zhu HH, Princen F, Fang DD, Han T, Bailly-Maitre B, Poli V, et al: Ptpn11/Shp2 acts as a tumor suppressor in hepatocellular carcinogenesis. Cancer Cell 19: 629-639, 2011.

13. Xiang D, Cheng Z, Liu H, Wang X, Han T, Sun W, Li X, Yang $\mathrm{W}$, Chen C, Xia M, et al: Shp2 promotes liver cancer stem cell expansion by augmenting $\beta$-catenin signaling and predicts chemotherapeutic response of patients. Hepatology 65: 1566-1580, 2017.

14. Tsutsumi R, Masoudi M, Takahashi A, Fujii Y, Hayashi T, Kikuchi I, Satou Y, Taira M and Hatakeyama M: YAP and TAZ, hippo signaling targets, act as a rheostat for nuclear SHP2 function. Dev Cell 26: 658-665, 2013.

15. Zheng H, Li S, Hsu P and Qu CK: Induction of a tumor-associated activating mutation in protein tyrosine phosphatase Ptpn11 (Shp2) Enhances mitochondrial metabolism, leading to oxidative stress and senescence. J Biol Chem 288: 25727-25738, 2013.

16. Hellmuth K, Grosskopf S, Lum CT, Würtele M, Röder N, von Kries JP, Rosario M, Rademann J and Birchmeier W: Specific inhibitors of the protein tyrosine phosphatase Shp2 identified by high-throughput docking. Proc Natl Acad Sci USA 105: 7275-7280, 2008

17. Zeng LF, Zhang RY, Yu ZH, Li S, Wu L, Gunawan AM, Lane BS, Mali RS, Li X, Chan RJ, et al: Therapeutic potential of targeting the oncogenic SHP2 phosphatase. J Med Chem 57: 6594-6609, 2014.

18. Liu W, Yu B, Xu G, Xu WR, Loh ML, Tang LD and and Qu CK: Identification of cryptotanshinone as an inhibitor of oncogenic protein tyrosine phosphatase SHP2 (PTPN11). J Med Chem 56: 7212-7221, 2013.

19. Zhang X, He Y, Liu S, Yu Z, Jiang ZX, Yang Z, Dong Y, Nabinger SC, Wu L, Gunawan AM, et al: Salicylic acid based small molecule inhibitor for the oncogenic src homology-2 domain containing protein tyrosine phosphatase-2 (SHP2). J Med Chem 53: 2482-2493, 2010.

20. Chen L, Pernazza D, Scott LM, Lawrence HR, Ren Y, Luo Y, Wu X, Sung SS, Guida WC, Sebti SM, et al: Inhibition of cellular Shp2 activity by a methyl ester analog of SPI-112. Biochem Pharmacol 80: 801-810, 2010.

21. Chen L, Sung SS, Yip ML, Lawrence HR, Ren Y, Guida WC, Sebti SM, Lawrence NJ and Wu J: Discovery of a novel shp2 protein tyrosine phosphatase inhibitor. Mol Pharmacol 70: 562-570, 2006.

22. Chen YP, LaMarche MJ, Chan HM, Fekkes P, Garcia-Fortanet J, Acker MG, Antonakos B, Chen CH, Chen Z, Cooke VG, et al: Allosteric inhibition of SHP2 phosphatase inhibits cancers driven by receptor tyrosine kinases. Nature 535: 148-152, 2016.

23. Chen C, Cao M, Zhu S, Wang C, Liang F, Yan L and Luo D: Discovery of a novel inhibitor of the protein tyrosine phosphatase Shp2. Sci Rep 5: 17626, 2015. 
24. Hartman ZR, Schaller MD and Agazie YM: The tyrosine phosphatase SHP2 regulates focal adhesion kinase to promote EGF-induced lamellipodia persistence and cell migration. Mol Cancer Res 11: 651-664, 2013.

25. Sausgruber N, Coissieux MM, Britschgi A, Wyckoff J, Aceto N, Leroy C, Stadler MB, Voshol H, Bonenfant D and Bentires-Alj M: Tyrosine phosphatase SHP2 increases cell motility in triple-negative breast cancer through the activation of SRC-family kinases. Oncogene 34: 2272-2278, 2015.

26. Zhang RY, Yu ZH, Zeng L, Zhang S, Bai Y, Miao J, Chen L, Xie J and Zhang ZY: SHP2 phosphatase as a novel therapeutic target for melanoma treatment. Oncotarget 7: 73817-73829, 2016

27. Sieg DJ, Hauck CR, Ilic D, Klingbeil CK, Schaefer E, Damsky CH and Schlaepfer DD: FAK integrates growth-factor and integrin signals to promote cell migration. Nat Cell Biol 2: 249-256, 2000

28. Zhang K, Zhao H, Ji Z, Zhang C, Zhou P, Wang L, Chen Q, Wang J, Zhang P, Chen Z, et al: Shp2 promotes metastasis of prostate cancer by attenuating the PAR3/PAR6/aPKC polarity protein complex and enhancing epithelial-to-mesenchymal transition. Oncogene 35: 1271-1282, 2016

29. Wang FM, Liu HQ, Liu SR, Tang SP, Yang L and Feng GS: SHP-2 promoting migration and metastasis of MCF-7 with loss of E-cadherin, dephosphorylation of FAK and secretion of MMP-9 induced by IL-1 $\beta$ in vivo and in vitro. Breast Cancer Res Treat 89: 5-14, 2005.

30. Grossmann KS, Wende H, Paul FE, Cheret C, Garratt AN, Zurborg S, Feinberg K, Besser D, Schulz H, Peles E, et al: The tyrosine phosphatase Shp2 (PTPN11) directs Neuregulin-1/ErbB signaling throughout Schwann cell development. Proc Natl Acad Sci USA 106: 16704-16709, 2009.
31. Huang YS, Cheng CY, Chueh SH, Hueng DY, Huang YF, Chu CM, Wu ST, Tai MC, Liang CM, Liao MH, et al: Involvement of SHP2 in focal adhesion, migration and differentiation of neural stem cells. Brain Dev 34: 674-684, 2012.

32. Inagaki K, Noguchi T, Matozaki T, Horikawa T, Fukunaga K, Tsuda M, Ichihashi $M$ and Kasuga $M$ : Roles for the protein tyrosine phosphatase SHP-2 in cytoskeletal organization, cell adhesion and cell migration revealed by overexpression of a dominant negative mutant. Oncogene 19: 75-84, 2000

33. Longley DB, Harkin DP and Johnston PG: 5-fluorouracil: Mechanisms of action and clinical strategies. Nat Rev Cancer 3: 330-338, 2003.

34. Fujinaka Y, Matsuoka K, Iimori M, Tuul M, Sakasai R, Yoshinaga K, Saeki H, Morita M, Kakeji Y, Gillespie DA, et al: ATR-Chk1 signaling pathway and homologous recombinational repair protect cells from 5-fluorouracil cytotoxicity. DNA Repair (Amst) 11: 247-258, 2012

35. Tsang YH, Han X, Man WY, Lee N and Poon RY: Novel functions of the phosphatase SHP2 in the DNA replication and damage checkpoints. PLoS One 7: e49943, 2012.

36. Bradham C and McClay DR: p38 MAPK in development and cancer. Cell Cycle 5: 824-828, 2006.

37. Koul HK, Pal M and Koul S: Role of p38 MAP kinase signal transduction in solid tumors. Genes Cancer 4: 342-359, 2013.

38. Mamik MK and Ghorpade A: Src homology-2 domain-containing protein tyrosine phosphatase (SHP) 2 and p38 regulate the expression of chemokine CXCL8 in human astrocytes. PLoS One 7: e45596, 2012. 